\title{
THE SYNTHESIS OF PHOSPHATE-REPRESSIBLE ALKALINE PHOSPHATASE DO NOT APPEAR TO BE REGULATED BY AMBIENT PH IN THE FILAMENTOUS MOULD NEUROSPORA CRASSA
}

\author{
Sérgio R. Nozawa' ${ }^{1}$ Geraldo Thedei Jr. ${ }^{2}$; Luciana S.P. Crott ${ }^{3}$; José E. Barbosa ${ }^{4}$; Antonio Rossi ${ }^{4 *}$ \\ ${ }^{1}$ Departamento de Química, Faculdade de Filosofia, Ciências e Letras de Ribeirão Preto, Universidade de São Paulo, Ribeirão \\ Preto, SP, Brasil. ${ }^{2}$ Instituto de Ciências da Saúde, Universidade de Uberaba, Uberaba, MG, Brasil. ${ }^{3}$ Departamento de Análises \\ Clínicas, Toxicológicas e Bromatológicas, Faculdade de Ciências Farmacêuticas de Ribeirão Preto, ${ }^{4}$ Departamento de \\ Bioquímica e Imunologia, Faculdade de Medicina de Ribeirão Preto, Universidade de São Paulo, Ribeirão Preto, SP, Brasil.
}

Submitted: November 08, 2001; Approved: March 07, 2002

\begin{abstract}
In order to investigate further the adaptive response of moulds to ambient $\mathrm{pH}$, we have measured by ELISA the pho-2-encoded Pi-repressible alkaline phosphatase synthesised by Neurospora crassa. We showed that the 74A and pho-2A strains of this mould secrete similar amounts of the pho-2-encoded enzyme irrespective of ambient $\mathrm{pH}$, when both the preg and pgov genes are not functional, i.e., in strains $n u c-2^{+}$growing under $\mathrm{Pi}-$ starvation. This suggests that pho-2, which is responsive to Pi starvation via the action of genes nuc-2, preg, pgov and nuc-1, is not a gene responsive to ambient $\mathrm{pH}$ and that the differential glycosylation observed for the Pi-repressible alkaline phosphatase retained by the mycelium at $\mathrm{pH} 5.6$ or secreted into the growth medium at $\mathrm{pH} 8.0$ is the genetic response to ambient $\mathrm{pH}$ sensing in $\mathrm{N}$. crassa.
\end{abstract}

Key words: alkaline phosphatase, ambient $\mathrm{pH}$, enzyme secretion, Neurospora crassa, Pi sensing

\section{INTRODUCTION}

The filamentous mould Neurospora crassa synthesises a number of Pi-repressible phosphatases and permeases that function to make more phosphate available to the cell, i.e., these enzymes are synthesised in response to the signalling of phosphorus starvation. The genetic and molecular mechanisms controlling this response in $N$. crassa include four regulatory genes, nuc-2, preg, pgov, and nuc-1, involved in a hierarchical relationship $(5,16)$. The action of the transcriptional activator NUC-1, required for the expression of genes such as pho-2 [which encodes a Pi-repressible alkaline phosphatase (APase)] (8), is antagonised by the putative PGOV-PREG complex, which is antagonised by NUC-2, which in turn is antagonised by Pi or its derivatives. Thus, NUC-1 is relieved from the negative effect of the PGOV-PREG complex in strains $n u c-2^{+}$growing under Pistarvation (20). In addition, the synthesis and secretion of these
Pi-repressible phosphatases are also under the action of nitrogen, carbon, and $\mathrm{pH}$ regulatory circuits $(9,18,23)$.

The extracellular $\mathrm{pH}$ is a key environmental signal that governs growth, differentiation, physiology and viability of all living organisms. In the mould Aspergillus nidulans these responses are mediated by a conserved signal transduction pathway comprising at least seven genes. The gene pac C codes for a $\mathrm{Zn}$-finger transcription factor that undergoes proteolysis at alkaline $\mathrm{pH}$, yielding a functional protein responsible for the induction of genes encoding products with optimal activity at alkaline $\mathrm{pH}$ (alkaline genes) and repression of those expressing products with optimal activity at acid $\mathrm{pH}$ (acid genes). Transcription of pac $\mathrm{C}$ is itself induced under alkaline growth conditions. The pal genes (palA, B, C, F, H, and I) are putative members of a signalling cascade involved in ambient alkaline $\mathrm{pH}$ sensing, whose sole known function is to promote the proteolytic activation of PACC $(6,13,14,15,23)$. However, it is

\footnotetext{
* Corresponding author. Mailing address: Departamento de Bioquímica e Imunologia, FMRP-USP. Av. Bandeirantes 3900. 14049-900, Ribeirão Preto, SP, Brasil. Phone: (+5516) 602-3112. Fax: (+5516) 633-6840. E-mail: anrossi@usp.br
} 
uncertain whether the conserved PACC pathway is the only mechanism that governs $\mathrm{pH}$-responsive gene expression. In $S$. cereviseae, induction of several genes at alkaline $\mathrm{pH}$ relies upon PACC-independent $\mathrm{pH}$ signaling mechanisms (13). In N. crassa, although gene pho-2 is induced irrespective of the growth $\mathrm{pH}$, an active enzyme is only extensively secreted into the growth medium at alkaline $\mathrm{pH}(2,9,11)$, a response that is also dependent on the glycosylation of the enzyme molecule $(19,22)$. In order to investigate further the ambient $\mathrm{pH}$ response, our first aim was to measure by ELISA the pho-2-encoded Pi-repressible APase synthesised by the 74A and pho-2A strains of the mould $N$. crassa. We observed the secretion of similar amounts of Pirepressible APase irrespective of ambient $\mathrm{pH}$, when NUC-1 is relieved from the negative effect of the putative PGOV-PREG complex in $n u c-2^{+}$strains growing in low-Pi medium.

\section{MATERIALS AND METHODS}

The St.L. 74A and pho-2A (FGSC 3061) strains of $N$. crassa are available from the Fungal Genetics Stock Center (University of Kansas Medical Center, Kansas City, KS, USA). The pho-2A strain was identified as carrying mutation in the structural gene for Pi-repressible alkaline phosphatase (8). Conidia from each strain $\left(5 \times 10^{7}\right.$ cells $)$ were grown for $72 \mathrm{~h}$ at $30^{\circ} \mathrm{C}$ without shaking on Petri dishes (14 cm diameter) containing $50 \mathrm{ml}$ high- $(10 \mathrm{mM})$ or low- $(50 \mu \mathrm{M})$ Pi-liquid medium adjusted to $\mathrm{pH} 5.4$ (nonbuffered) or 7.8 (buffered with $50 \mathrm{mM}$ Tris-HCl) (17), supplemented with $44 \mathrm{mM}$ sucrose as carbon source, and prepared as previously described (3). The harvested mycelium extracted with sand and $50 \mathrm{mM}$ sodium acetate buffer $(40 \mathrm{ml}$ buffer $\mathrm{g}^{-1}$ mycelium), $\mathrm{pH} 5.4$, was subsequently centrifuged for $20 \mathrm{~min}$ at $20,000 \mathrm{x} \mathrm{g}$ at $4^{\circ} \mathrm{C}$, and the supernatant was dialysed for $24 \mathrm{~h}$ against two 1 of phosphate-buffered saline (PBS buffer) (with one change) and stored at $-20^{\circ} \mathrm{C}$ (mycelial crude extract). An appropriate volume of the harvested culture medium was concentrated about 10 times by ultrafiltration through AMICON (YM10) membranes, dialysed for $24 \mathrm{~h}$ against two 1 PBS buffer (with one change), and stored at $-20^{\circ} \mathrm{C}$ (culture medium).

The pho- $2^{+}$-encoded Pi-repressible APase retained by the mycelium or secreted into the growth medium by the 74A strain of the mould $N$. crassa grown on low-Pi medium, pH 7.8, was purified as described previously by Palma et al. (19) and Thedei and Rossi (21), respectively. Antibodies were raised in two albino male rabbits which were respectively immunised with the pho- $2^{+}$-encoded Pi-repressible APase purified from mycelium $(250 \mu \mathrm{g})$ and from culture medium $(160 \mu \mathrm{g})$ and emulsified in complete Freund's adjuvant. After one month, a booster injection of these enzymes was given and blood was collected weekly starting one week after the first booster injection. Serum positivity was tested by the double immunodiffusion assay as previously described (10). The IgG present in sera was purified to apparent homogeneity as determined by SDS-PAGE as follows: briefly, the IgG recovered in the 0-33\% $\left(\mathrm{NH}_{4}\right)_{2} \mathrm{SO}_{4}$ saturation was solubilised in PBS buffer and successively dialysed against PBS buffer for $24 \mathrm{~h}$ at $4^{\circ} \mathrm{C}$ (with one change), and $0.02 \mathrm{M}$ potassium phosphate buffer, $\mathrm{pH}$ 7.5 , for $24 \mathrm{~h}$ at $4^{\circ} \mathrm{C}$ (with one change). The dialysed IgG fraction was applied to a column $(2 \times 60 \mathrm{~cm})$ of DEAE-cellulose previously equilibrated with the phosphate buffer used for dialysis and was eluted at room temperature with this same buffer at a flow rate of $60 \mathrm{ml} \mathrm{h}^{-1}$ (five $\mathrm{ml}$ fractions). The tubes representing the $\mathrm{IgG}$ fraction were pooled, concentrated by ultrafiltration through AMICON (YM10) membranes, and stored at $4^{\circ} \mathrm{C}$. In a double immunodiffusion assay the anti-mycelial $\mathrm{Pi}$ repressible alkaline phosphatase antibody recognised the secreted Pi-repressible alkaline phosphatase and vice versa.

The enzymatic assay was carried out in $0.3 \mathrm{M}$ glycine buffer, pH 9.0, containing one mM EDTA using six mM p-nitrophenyl phosphate (PNP-P) as the substrate, a specific cocktail used to assay the Pi-repressible APase from N. crassa (17). One unit of enzyme activity was defined as one mmol substrate hydrolysed $\mathrm{h}^{-1}$, at $37^{\circ} \mathrm{C}$. Specific activities were expressed as Units (mg dry weight mycelium $)^{-1}$. The S. D. was calculated from three replicates. At least two independent experiments were carried out. Protein was measured by the method of Folin as described by Hartree (12) using bovine serum albumin as the standard.

Quantification of Pi-repressible APase [ $\mu \mathrm{g}$ protein (mg dry weight mycelium $)^{-1}$ ] was performed by ELISA. Briefly, samples of mycelial crude extracts and culture media obtained after growth of strains 74A and pho-2A in high- or low-Pi, pH 5.4 or 7.8, were diluted in $0.1 \mathrm{M}$ sodium carbonate buffer, $\mathrm{pH} 9.6$, added to highaffinity 96-well plates (NUNC Immunoplates) $\left(100 \mu \mathrm{l} \mathrm{well}^{-1}\right)$, and incubated overnight at $4^{\circ} \mathrm{C}$. The plates were washed with PBS buffer-Tween 20, and $200 \mu$ well $^{-1}$ of PBS buffer-Tween 20 containing $1 \%(\mathrm{w} / \mathrm{v})$ gelatin was added to block non-specific binding. After incubation for two $\mathrm{h}$ at $37^{\circ} \mathrm{C}$ the plates were washed with PBS buffer-Tween 20 , incubated for one $\mathrm{h}$ at $37^{\circ} \mathrm{C}$ with specific rabbit anti-alkaline phosphatase $\left(100 \mu \mathrm{l} \mathrm{well}^{-1}\right)$ at 1/1000 dilution, washed again with PBS buffer-Tween 20, and $100 \mu \mathrm{l} \mathrm{well}{ }^{-1}$ of polyclonal goat anti-rabbit immunoglobulin labelled with peroxidase (Sigma) was added at 1/3000 dilution. After the plates were incubated for one $h$ at $37^{\circ} \mathrm{C}$ and washed again with PBS buffer-Tween 20, peroxidase substrate (orthophenylene-diaminobenzidine, one $\mathrm{mg} \mathrm{ml}^{-1}$ ) was added, and A was read at $492 \mathrm{~nm}$ in an ELISA plate reader. Calculations were made using a standard curve prepared from purified phosphatases.

\section{RESULTS}

Fig. 1 shows that the 74A and pho-2A strains of $N$. crassa grown on low-Pi medium synthesise and secrete almost the same amounts of the pho-2-encoded Pi-repressible APase irrespective of the growth $\mathrm{pH}$ as measured by ELISA, but strain 


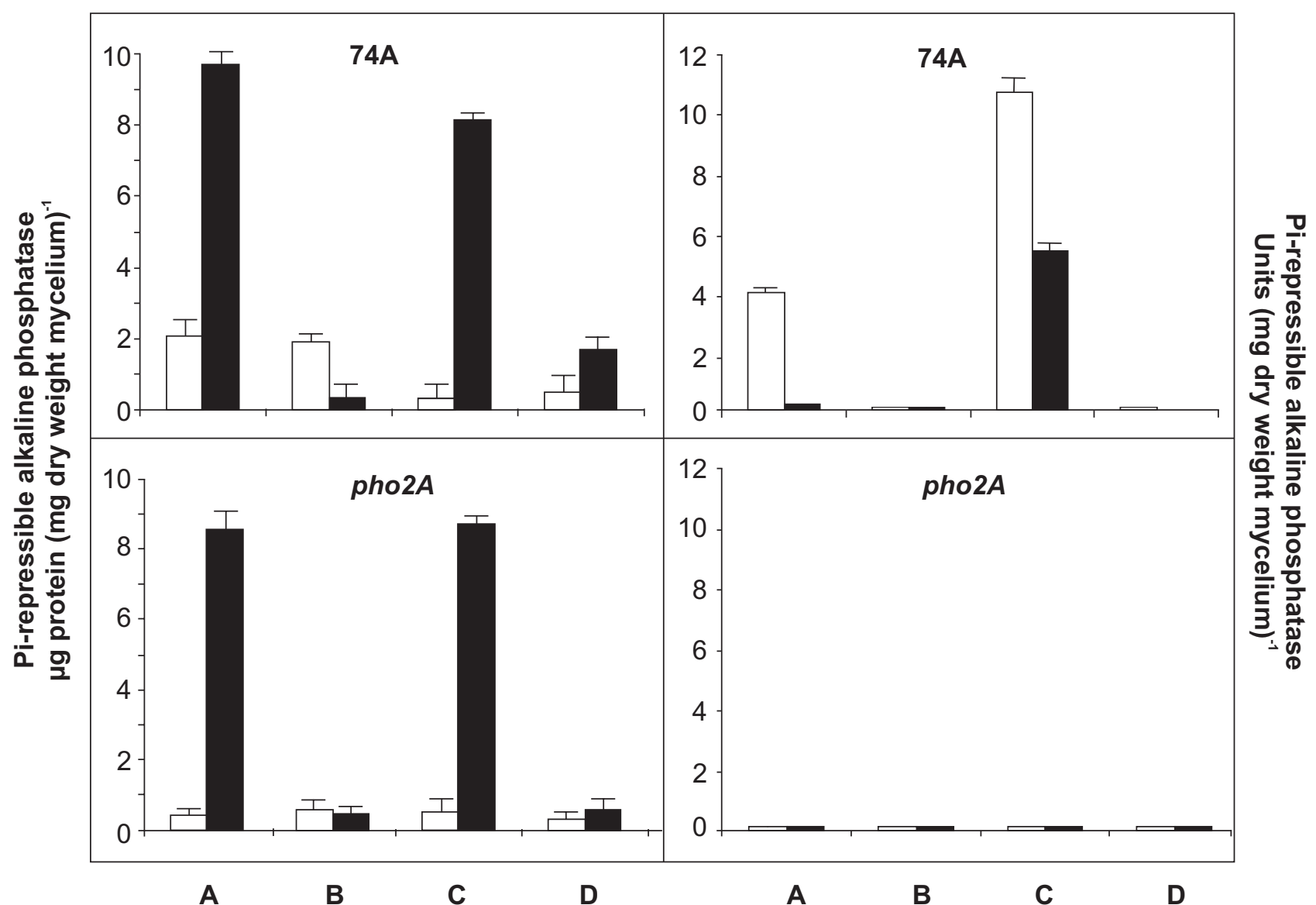

Figure 1. Effect of both growth $\mathrm{pH}$ and $\mathrm{Pi}$ concentration on the synthesis and secretion of the pho-2-encoded Pi-repressible alkaline phosphatase by the 74A and pho-2A strains of the mould Neurospora crassa. A and C represent growth in $50 \mu \mathrm{M} \mathrm{Pi}$ at pH 5.4 or pH 7.8, respectively. B and D represent growth in $10 \mathrm{mM} \mathrm{Pi}$ at pH 5.4 or pH 7.8, respectively. $\square$ and $\mathbf{m}$ represent mycelial and secreted Pi-repressible alkaline phosphatase, respectively.

74A secretes into the growth medium an enzyme tailored to resist alkaline $\mathrm{pH}$. We assumed that these enzyme forms are the product of the same pho-2 gene because the pho-2A strain did not reveal any active Pi-repressible APase (Fig. 1). It is also clear from Fig. 1 that gene pho-2 is repressed at the transcriptional level in high-Pi medium.

\section{DISCUSSION}

$\mathrm{pH}$ regulation has been implicated in the secretion by $N$. crassa of enzymes with optimal activity at acid or alkaline $\mathrm{pH}$ as a function of ambient $\mathrm{pH}$, i.e., acid and alkaline Pi-repressible phosphatases are, for example, secreted into the growth medium at acid or alkaline $\mathrm{pH}$, respectively (9). Furthermore, the $\mathrm{pH}$ dependent glycosylation of Pi-repressible APase was postulated (19) because the neutral sugar content of the enzyme purified from mycelium grown on sucrose at $\mathrm{pH} 5.4$ or from culture medium after growth at $\mathrm{pH} 7.8$ was about $13 \%$ and $21 \%$, respectively, which could account for the distinct structural and kinetic properties observed for these isoforms (21). Interestingly, the secretion of Pi-repressible APase is not repressed at acid $\mathrm{pH}$ because almost the same amount of this enzyme is secreted irrespective of ambient $\mathrm{pH}$ as measured by ELISA (Fig. 1). The loss of enzymatic activity observed for the Pi-repressible APase secreted by the 74A strain at $\mathrm{pH} 5.4$ is an effect probably due to the lower glycosylation level of this enzyme molecule as compared to the glycosylation level observed for the enzyme secreted at alkaline $\mathrm{pH}(19,21)$. Thus, $N$. crassa secretes similar amounts of the pho-2-encoded Pirepressible enzyme irrespective of ambient $\mathrm{pH}$ when both the preg and pgov genes are non-functional, i.e., in strains $n u c-2^{+}$ growing in low-Pi medium.

In conclusion, the above results lead us to believe that gene pho-2, which is responsive to Pi starvation via the action of genes nuc-2, preg, pgov and nuc-1, not only relied upon PacCindependent $\mathrm{pH}$ signalling mechanisms $(1,4,7,13)$ but also is 
not an alkaline gene. Furthermore, it is plausible that signalling mechanisms involved for example in post-transcriptional and/or post-translational processing of the Pi-repressible phosphatases, is somehow the adaptive genetic response to ambient $\mathrm{pH}$ sensing in $N$. crassa.

\section{ACKNOWLEDGEMENTS}

This research was supported by FAPESP, CNPq and CAPES. S.R.N. was supported by a studentship from FAPESP. We thank Newton R. Alves and Cláudia H.M. Avelar for technical assistance.

\section{RESUMO}

\section{A síntese da fosfatase alcalina Pi-repressível não parece ser regulada pelo $\mathrm{pH}$ ambiente no fungo filamentoso Neurospora crassa}

Para investigar a resposta adaptativa ao $\mathrm{pH}$ ambiente em fungos, foram determinados por ELISA os níveis de fosfatase alcalina Pi-repressível expressada pelo gene pho-2 de Neurospora crassa. Foi mostrado que as linhagens 74A e pho-2A deste fungo secretam quantidades semelhantes da fosfatase alcalina Pirepressível independentemente do $\mathrm{pH}$ ambiente, quando ambos os genes preg e pgov não são funcionais, isto é, quando a linhagem $n u c-2^{+}$cresce em condições de limitação em fosfato inorgânico (Pi). Isto sugere que o gene $p h o-2$, o qual é regulado pela ação hieráquica dos genes $n u c-2$, preg, pgov e nuc-1, é reprimido pelo fosfato inorgânico, mas não responde ao $\mathrm{pH}$ ambiente, e que a diferença na glicosilação observada para a fosfatase alcalina Pirepressível (APase) retida no micélio em pH 5,6 ou APase secretada no meio de cultura em $\mathrm{pH}$ 8,0 é a resposta genética para o monitoramento do $\mathrm{pH}$ ambiente em $N$. crassa.

Palavras-chave: fosfatase alcalina, Neurospora crassa, $\mathrm{pH}$ ambiente, secreção de enzimas

\section{REFERENCES}

1. Barkani, A.E.; Kurzai, O.; Fonzi, W.A.; Ramon, A.; Porta, A.; Frosch, M.; Mühlschlegel, F.A. Dominant active alleles of RIM101 (PRR2) bypass the $\mathrm{pH}$ restriction on filamentation of Candida albicans. Mol. Cell. Biol., 20: 4635-4647, 2000.

2. Carmona, E.C.; Han, S.W.; Palma, M.S.; Rossi, A. Properties of a polynucleotide synthesized by strain 74A of Neurospora crassa. Phytochemistry, 41: 345-348, 1996.

3. Crocken, B.; Nyc, J.F. Utilization of L-a-glycerophosphoryl-choline by a lectin-deficient strain of Neurospora crassa. Can. J. Microbiol., 9: 689-696, 1963.
4. Davis, D.; Wilson, R.B.; Mitchell, A.P. RIM101-dependent and independent pathways govern $\mathrm{pH}$ responses in Candida albicans. Mol. Cell. Biol., 20: 971-978, 2000.

5. Davis, R.H. Neurospora Contributions of a Model Organism. Oxford University Press, New York, 2000, 333p.

6. Denison, S.H. pH regulation of gene expression in fungi. Fung. Genet. Biol., 29: 61-71, 2000.

7. Espeso, E.A.; Roncal, T.; Diez, E.; Rainbow, L.; Bignell, E.; Álvaro, J.; Suárez, T.; Denison, S.H.; Tilburn, J.; Arst, H.N. Jr.; Peñalva, M. On how a transcription factor can avoid its proteolytic activation in the absence of signal transduction. EMBO J., 19: 719-728, 2000.

8. Grotelueschen, J.; Peleg, Y.; Glass, N.L.; Metzenberg, R.L. Cloning and characterization of $p h o-2^{+}$gene encoding a repressible alkaline phosphatase. Gene, 144: 147-148, 1994.

9. Grove, G.; Marsluf, G.A. Nitrogen regulation of acid phosphatase in Neurospora crassa. J. Bacteriol., 141: 1470-1473, 1980.

10. Han, S.W.; Michelin, M.A.; Barbosa, J.E.; Rossi, A. Purification and constitutive excretion of acid phosphatase in Neurospora crassa. Phytochemistry, 35: 1131-1135, 1994.

11. Han, S.W.; Nahas, E.; Rossi, A. Regulation of synthesis and secretion of acid and alkaline phosphatases in Neurospora crassa. Curr. Genet. 11: 521-527, 1987.

12. Hartree, E.F. Determination of protein: a modification of Lowry method that gives a linear photometric response. Anal. Biochem. 48: 422-427, 1972.

13. Lamb, T.M.; Xu, W.; Diamond, A.; Mitchell, A.P. Alkaline response genes of S. cerevisiae and their relationship to the RIM101 pathway. J. Biol. Chem., 276: 1850-1856, 2001.

14. Maccheroni, W. Jr.; May, G.S.; Martinez-Rossi, N.M.; Rossi, A. The sequence of palF, an environmental $\mathrm{pH}$ response gene in Aspergillus nidulans. Gene, 194: 163-167, 1997.

15. Maccheroni, W. Jr.; May, G.S.; Martinez-Rossi, N.M.; Rossi, A. The levels of mRNA expressed by gene palF of A. nidulans do not appear to be pH regulated. Fung. Genet. News., 47: 72-73, 2000

16. Metzenberg, R.L. Implications of some genetic control mechanisms in Neurospora. Microbiol. Rev., 43: 361-383, 1979.

17. Nahas, E.; Rossi, A. Properties of repressible alkaline phosphatase secreted by the wild-type strain 74A of Neurospora crassa. Phytochemistry, 23: 507-510, 1984

18. Nahas, E.; Terenzi, H.F.; Rossi, A. Effect of carbon source and $\mathrm{pH}$ on the production and secretion of acid phosphatase (EC 3.1.3.2) and alkaline phosphatase (EC 3.1.3.1) in Neurospora crassa. J. Gen. Microbiol., 128: 2017-2021, 1982.

19. Palma, M.S.; Han, S.W.; Rossi, A. Dissociation and catalytic activity of phosphate-repressible alkaline phosphatase from Neurospora crassa. Phytochemistry, 28: 3281-3284, 1989.

20. Peleg, Y.; Addison, R.; Aramayo, R.; Metzenberg, R.L. Translocation of Neurospora crassa transcription factor NUC-1 into the nucleus is induced by phosphorus limitation. Fung. Genet. Biol., 20: 185-191, 1996.

21. Thedei Jr.; G.; Rossi, A. Is the sense of Pi levels abolished in the preg $^{\mathrm{c}}$ strain of the mold Neurospora crassa? Plant Cell Physiol., 35: 837-840, 1994.

22. Thedei Jr. G.; Nozawa, S.R.; Simões, A.L.; Rossi, A. Gene pho-2 codes for the multiple active forms of Pi-repressible alkaline phosphatase in the mold Neurospora crassa. World J. Microbiol. Biotechnol., 13: 609-611, 1997.

23. Tilburn, J.; Sarkar, S.; Widdick, D.A.; Espeso, E.A.; Orejas, M.; Mungroo, J.; Peñalva, M.A.; Arst, H.N. Jr. The Aspergillus PacC zinc finger transcription factor mediates regulation of both acidand alkaline-expressed genes by ambient $\mathrm{pH}$. EMBO J., 14: 779$790,1995$. 